\title{
Live Animal Dosage Form
}

National Cancer Institute

\section{Source}

National Cancer Institute. Live Animal Dosage Form. NCI Thesaurus. Code C157383.

A type of pharmaceutical dose form consisting of a whole, live animal used as a medicinal product, which may have a mechanical function and/or deliver physiologically active substances. 